\section{啉阐 Digital Commons@}

Loyola Marymount University

LMU Loyola Law School
Loyola of Los Angeles International and Comparative Law Review

6-1-2005

\title{
The Development of the Securities Market and Regulation in \\ China
}

Yuwa Wei

Follow this and additional works at: https://digitalcommons.Imu.edu/ilr

Part of the Law Commons

\section{Recommended Citation}

Yuwa Wei, The Development of the Securities Market and Regulation in China, 27 Loy. L.A. Int'I \& Comp. L. Rev. 479 (2005).

Available at: https://digitalcommons.Imu.edu/ilr/vol27/iss3/4

This Article is brought to you for free and open access by the Law Reviews at Digital Commons @ Loyola Marymount University and Loyola Law School. It has been accepted for inclusion in Loyola of Los Angeles International and Comparative Law Review by an authorized administrator of Digital Commons@Loyola Marymount University and Loyola Law School. For more information, please contact digitalcommons@lmu.edu. 


\title{
The Development of the Securities Market and Regulation in China
}

\author{
YUWA WEI ${ }^{*}$
}

\section{INTRODUCTION}

Since China's economic reforms, securities activities have reappeared in China. In 1986, John Phelan, Chairman of the Board of the New York Stock Exchange (NYSE), presented the emblem of the NYSE as a gift to the then President of China, Deng Xiaoping. In return, the President of the Bank of China gave Mr. Phelan the first green-colored stock certificate in the history of the People's Republic of China, the stock of the Shanghai Feile Acoustics Company. In fact, the stock of the Shanghai Feile Acoustics Company was first issued in 1984. Excited, Mr. Phelan requested a visit to the first stock exchange in China. Mr. Phelan had a positive first impression of the Shanghai Jingan Stock Exchange, a room of about eleven square meters located in a building on Nanjing Xilu Road in Shanghai. Mr. Phelan commented that the Shanghai Jingan, in its nascency, was superior to the NYSE due to the fact that the initial transactions of the NYSE were completed under a tree.

Since Mr. Phelan's first visit, China has not only established two national stock exchanges, but the trading value of the stock

- LL.B. (China University of Political Science and Law, Beijing, China); LL.M. (Bond University, Australia); Ph.D. (Bond University, Australia); Lecturer in Law, Monash University, Australia; Honorary Professor, Harbin University of Science and Technology, China; Fellow, Tim Fischer Center for Global Trade \& Finance, Bond University.

The research of this article was supported by Monash Small Research Grants Scheme (small ARC grants Scheme). The author wishes to acknowledge the Faculty of Law at Monash University and Australian Research Council for this support.

1. ZHONG CHEN, Wind AND CLOUd ON THE SECURITIES MARKETS IN CHINA 91 (2d ed. 2000).

2. Id. at 92 . 
exchanges accounts for fifty percent of China's GDP. ${ }^{3}$ As a result of China's entry into the WTO, its securities market has opened further to foreign investors. China's securities market has caught worldwide attention.

This Article investigates the role of the securities market in relation to corporate governance, and examines how the Chinese utilize the monitoring functions of the securities market to upgrade their corporate governance systems. This Article also explores other influential securities markets, and provides a comparative discussion on the securities regulations and practice in these systems.

Part II investigates the theoretical aspects of the securities market and its regulations. It examines the important role played by the securities market in the economy, and its value-creating capacity function. This section illustrates the rationalities behind the development of the securities market, and then analyses its significant supervisory function over the management of listed companies.

Part III traces the tortuous path of the development of the securities market in China. In doing so, it also compares securities laws and practices in leading economies such as the United States, the United Kingdom, Germany, and Japan. In addition, this section demonstrates that the development of the securities market and regulation is shaped by the particular social, political, and economic circumstances of a particular country.

Part IV analyses the characteristics and identifies the problems of securities laws and practices in China. This Section draws a comparison between China's situation and the situations of mature markets, and suggests that China needs to further promote the banks' role in corporate finance.

Part V concludes that China's securities market has come into a crucial stage of development. Designing a securities regime in China is an uphill task. China must reduce government intervention for the market to operate under market rules. Additionally, China should develop a securities regime that combines the strengths of the market-based approach and the bank-based approach.

3. By September 2001, trading value of the stock exchanges accounted for $51.26 \%$ of China's GDP. See Jin DeHUan, A STUdy of Volatility of THE Chinese SECURITIES MARKET AND CONTROL 4 (2003). 


\section{A MEANS OF CORPORATE FINANCE AND AN EXTERNAL MECHANISM OF CORPORATE GOVERNANCE}

The Chinese government has been motivated by three major objectives in developing a securities market: (1) encourage securities investments and mitigate the lack of capital resources faced by many Chinese enterprises; (2) maximize employment of idle capital; and (3) establish a modern corporate governance system in listed companies." Unlike some developed countries, China attaches great importance to the monitoring function of the securities market over the management of listed companies. ${ }^{5}$ In fact, using the securities market as leverage to speed-up the process of building a modern corporate governance system has been an important reform strategy of the Chinese government. ${ }^{6}$ The expectations of the Chinese are based on the two fundamental functions of the securities market: corporate finance and corporate governance. This section will examine these two functions in turn.

In a highly competitive commercial environment, corporations race for survival. In this race, large corporations have a better chance of surviving. This is because the expansion of

4. See generally Daniel M. Anderson, Taking stock in China: Company disclosure and information in China's stock markets, GEO. L.J. (Jun. 2000).

5. Stephen C. Thomas \& Chen Ji, Privatizing China: The Stock Markets and Their Role in Corporate Reform, 58 China Bus. Rev. (July 1, 2004) (book review) (2004 WLNR 11626777).

6. The author of this article had interesting discussions with the staff members of China Securities Regulatory Commission and Hong Kong Stock Exchange during conferences in 2001 and 2003 . The staff members clarified that by encouraging statecontrolled companies to be listed on stock exchanges, the Chinese government hoped that these companies would accelerate the process of modernizing their management and promoting the practice of good corporate governance. They further pointed out that these state-controlled companies have state banks to be their financiers and their main purpose of going public was not raising funds from the securities market. See Yuwa Wei, The Role of China Securities Regulatory Commission in Corporate Law Reforms and Corporate Governance, Paper Presented at the DEST (CHESI) Melbourne Conference: Corporate Governance in Post WTO China, 11 passim (Dec. 5-6, 2003) (on file with author). (manuscript presented at the International Conference on Corporate Governance in PostWTO Entry China, Melbourne, Dec.2003).

7. Xiao Geng, China's Securities Market Development: Lessons from Hong Kong and Other Asian Markets 1, 3 (Jan. 15, 2003) at http://www.econ.hku.hk/ xiaogeng/research/Paper/Securities\%20market\%20development $\% 20$ in $\% 20$ China-English.pdf (discussing the role of the stock market in company finance and governance); see also Yuwa Wei, Seeking a Practicable Chinese Model of Corporate Governance, 10 MICH. ST. U.-DSL J. INT'L. L. 393, 426 (2002) (asserting that China benefited from the monitoring function of the securities market).

8. See Alfred D. Chandler, JR., SCAle AND SCOPE: THE DYNAMics OF INDUSTRIAL CAPITALISM 8, 953-56 (1990) (stating that large manufacturing companies 
business scales can reduce unit costs and increase the total longrun profits. ${ }^{9}$ Also, large-scale corporations have the advantage of attracting top managerial talents and skilled workers. ${ }^{10}$ Corporations must grow." Consequently, they must expand their business scale and scope to increase their total long-run profits. To facilitate this growth, corporations need funds which energized the development of the Securities Market worldwide. ${ }^{12}$

The security market is a place where corporations and individuals buy and sell securities. For corporations, issuing securities on a stock exchange is an important means of raising funds. ${ }^{13}$ Alternatively, a corporation could also directly borrow funds from financial institutions, or issue shares and debentures to specific investors. Such financial arrangements, however, have limits. For example, bank loans would burden companies with high interest costs. Moreover, it is difficult to find specific investors when the amount of funds needed is extensive. Consequently, raising funds from the general public becomes a crucial means of boosting corporate finance.

The securities market and banks played important roles at every stage of corporate development, from the early joint stock companies to modern public listing companies, and from early railway, shipping, and mining industries to our modern aviation, space, and information technology industries. ${ }^{14}$ In common law systems, the rise of the corporate economy relied on attracting and

enjoyed powerful competitive advantages).

9. Id. at 953 .

10. James C. Cooper \& Kathleen Madigan Small Isn't Beautiful When Skills are Scarce Business Week: Enterprise Online (Oct. 2, 1995), at http://www.businessweek.net/ 1995/40/b3444129.htm.

11. See Edith T. PENRose, The Theory of The Growth of THE Firm 30 (1980) ("[G]rowth and profits become equivalent as the criteria for the selection of investment programs. Firms will never invest in expansion for the sake of growth if the return on the investment is negative, for that would be self-defeating. Firms will never invest outside the firm except eventually to increase the funds available for investment in the firm. To increase total long-run profits of the enterprise in the sense discussed here is therefore equivalent to increasing the long-run rate of growth. Hence, it does not matter whether we speak of 'growth' or 'profits' as the goal of a firm's investment activities.").

12. See generally E.VICTOR MORGAN \& W.A. THOMAS, THE STOCK EXCHANGE: ITS HISTORY AND FUNCTIONS (1969).

13. JAMES D. COX, ET AL., Securities Regulation CASES AND Materials 2 (3rd ed. 2001).

14. See E. Victor Morgan \& W.A. Thomas, THe Stock Exchange: ITS HISTORY AND FUNCTIONS (2nd ed. 1969) (tracing the history of the stock exchange and its huge expansion since 1914). 
utilizing public investments. ${ }^{15}$

The securities market not only enables corporations to raise capital from a wide range of investors, but the securities market also acts as a monitoring mechanism over the management of corporations. $^{16}$ This is because share prices closely reflect the managerial efficiency of corporations. ${ }^{17}$ Specifically, investors are reluctant to invest in a poorly managed company. As a result, the share prices of poorly managed companies are likely to go down, thereby exposing these companies as targets for takeovers. The threat of takeover acts as a deterrent that obliges the board and management to act in the interests of the corporation. ${ }^{18}$ In the meantime, the benefits of being listed on a stock exchange provide incentives for corporations to actively improve their economic and managerial efficiency to satisfy the listing requirements of stock exchanges. ${ }^{19}$

The securities market is subject to rigorous regulation because of its profit-making function. ${ }^{20}$ Over time, the securities market experienced eras of free trade, regulation, and deregulation. Initially, the securities market was basically unregulated, which led to a series of crises and scandals. ${ }^{21}$ For instance, the burst of the South Sea Bubble in the early 18th century caused the collapse of the entire financial market in the United Kingdom. ${ }^{22}$ In the United States, the failure of the

15. See MORGAN \& THOMAS, supra note 14 .

16. Michael C. Jensen \& William H. Meckling, Theory of the Firm: Managerial Behavior, Agency Costs and Ownership Structure, 3 J. FIN. ECON. 305, 323 (1976) (arguing the stock market could control management through monitoring).

17. See generally id.; R. Ian McEwin, Law and Economics as an Approach to Corporate Law Research, 3 CANBERRA L. REV. 40, 41 (1996); WILlIAM J. BAUMOL \& ALAN BLINDER, ECONOMICS, PRINCIPLES AND POLICY 647 (1988).

18. Thomas Lee Hazen, The Short-Term/Long-Term Dichotomy and Investment Theory: Implications for Securities Market Regulation and for Corporate Law, 70 N.C.L. Rev. 137, 182 (1991) (discussing how the threat of takeover keeps management focused on its value-maximizing function).

19. See Paul Marsh, Market Assessment of Company Performance, in CAPITAL MARKETS AND CORPORATE GOVERNANCE 67 (Nicholas Dimsdale and Martha Prevezer eds. 1994). See also Colin Mayer, Stock-markets, Financial Institutions, and Corporate Performance, in CAPITAL MARKETS AND CORPORATE GOVERNANCE 179 (Nicholas Dimsdale and Martha Prevezer eds. 1994).

20. See Thomas lee hazen, The law of Securities Regulation 8 (3rd ed. 1996).

21. Id. at 6 .

22. See LewiS Melville, ThE SOUTH SEA Bubble-vii (1921) (threatening the nation with political and social ruin); PETER GEORge MUIR Dickson, THE FINANCIAL REVOLUTION IN ENGLAND (1967). 
securities market added further devastation to the economic depression in the 1930s. ${ }^{23}$ Following these failures, rules and regulations were introduced to make the securities market a fair and orderly place for public investments. ${ }^{24}$ Now, in a fair and orderly securities market, investors are reasonably informed and the market has the ability to assess the performance of public companies, and supervise their management. ${ }^{25}$

In summary, the securities market has the following functions: (1) it provides a mechanism for companies to sell securities in order to finance corporate expansion; (2) it provides a means for investors to buy and sell their outstanding shares; (3) it establishes share prices that assist in monitoring firms and allocating resources; (4) it encourages risk-taking by spreading risks and rewarding profitable investment; and (5) through corporate control, it allows managerial failure to be corrected through its markets. ${ }^{26}$

In a well-functioning securities market, companies can raise new funds and investors can buy and sell outstanding securities at a fair price. ${ }^{27}$ However, there have always been doubts on the efficiency of the securities market in pricing its securities. Indeed, there has been evidence of mis-pricing. ${ }^{28}$ Otherwise, the securities market is efficient. ${ }^{29}$ Furthermore, improving financial reporting, disclosure, and quality of investment analysis could improve efficiency. ${ }^{30}$ As a result, investors are still confident enough to invest in securities.

23. See John P. Caskey, The Evolution of the Philadelphia Stock EXCHANGE: 1964-2002 8 (Research Dep't, Fed. Reserve Bank of Phila. Working Paper No. 03-21, 2003).

24. Louis Loss \& JOEl Seligman, Fundamentals of SECURITIES REgulation 34, 36 (5th ed. 2004) (discussing the Securities Act of 1933 and Securities Exchange Act of 1934).

25. See Arthur R. Pinto, The United States, in THE LeGal Basis of CoRPORATE GovernanCE IN PUBliCly Held CoRPorations 253, 258 (Arthur R. Pinto \& Gustavo Visentini eds., 1998); Daniel R. Fischel, Efficient Capital Market Theory, the Market for Corporate Control, and the Regulation of Cash Tender Offers, 57 TEX. L. REV. 1, 9 (1980).

26. Colin Mayer, Stock-markets, Financial Institutions, and Corporate Performance, in CAPITAL MARKETS AND CORPORATE GOVERNANCE 179 (Nicholas Dimsdale \& Martha Prevezer eds., 1994); Paul Marsh, Market Assessment of Company Performance, in CAPITAL MARKeTs AND CORPORATE GovernanCE 66, 67 (Nicholas Dimsdale \& Martha Prevezer eds. 1994).

27. Marsh, supra note 26, at 67.

28. Marsh, supra note 26 , at 69-70.

29. See id.

30. See Marsh, supra note 26 , at $84-90$. 
A well-functioning securities market also acts as an important mechanism for corporate governance in public companies. ${ }^{31}$ It encourages public companies to improve managerial efficiency and correct managerial failure in order to be admitted into a stock exchange and maintain their profiles. ${ }^{32}$ This is because companies must comply with the listing rules of the stock exchange. ${ }^{33}$ Also, once there, the share price of a company reflects the managerial efficiency of the company. ${ }^{34}$ Because of the low share price, a poorly managed company faces the threat of takeover. A takeover inevitably replaces the under-performing management team. Hence, takeovers contribute to the governance process in two ways: (1) the possibility of a takeover encourages management to act in the interests of the shareholders or the corporation as a whole $;^{36}$ and (2) most likely, a takeover would seek to remedy the problems caused by unsuccessful incumbent management by replacing it.

Because of these reasons, takeovers become an effective mechanism for corporate governance. ${ }^{38}$ Yet, that takeovers themselves merely provide an external mechanism for corporate governance and should be employed only as last resort, namely after internal governance mechanisms have failed. ${ }^{39}$

On the other hand, many people doubt that takeovers provide a natural remedy to corporate inefficiency. ${ }^{40}$ They point out that takeovers do not always push corporations to improve management. ${ }^{41}$ They believe that takeovers could encourage

31. Pinto, supra note 25, at 258.

32. Clyde E. Rankin, III, Unites States Corporate Governance: Implications for Foreign Issuers, in TRENDS AND DEVELOPMENTS IN CORPORATE GOVERNANCE 286, 291 (Dennis Campbell ed., 2003) (noting that the SEC requires a statement of management responsibilities and the $S \& P$ evaluates corporate governance of companies).

33. Id. at 266.

34. Pinto, supra note 25 , at 258 (discussing the efficient capital market hypothesis); Fischel, supra note 25 , at 1.

35. Fischel, supra note 25 , at 9.

36. See Pauline O'Sullivan, Governance by Exit: An Analysis of the Market for Corporate Control, in CORPORATE GOVERNANCE: ECONOMIC AND FINANCIAL ISSUES 122, 122-23 (Kevin Keasey, et al., eds. 1997); see also Pinto, supra note 25, at 273.

37. See O'Sullivan, supra note 36 , at 122-23.

38. RoBERT W. HAMILTON \& JoNATHAN R. MACEY, CASES AND MATERIALS ON CORPORATIONS INCLUDING PARTNERSHIPS AND LIMITED LIABILITY COMPANIES 662 (8th ed. 2003).

39. See O'Sullivan, supra note 36 , at $122-23$.

40. Hazen, supra note 18, at 182.

41. See id. at 182-83. 
corporate managers to focus on short-term performance, since the "pressures from the financial markets often drive them to engage in perverse behaviour that reduces long-term value". ${ }^{42}$ Particularly, managers may make business decisions just to frustrate potential takeovers. For example, company managers may try to make themselves indispensable, and therefore, costly to replace. ${ }^{43}$ In addition, studies have shown that the shareholders of the bidder company may be worse off after the takeover. ${ }^{44}$

This further suggests that, to enhance the efficiency of the securities market and its control function, it is necessary to introduce regulatory mechanisms over the securities market and securities business. Presently, the regulatory systems in developed countries, particularly the countries of leading economies, are based on longstanding practices, and thus are basically well established. ${ }^{45}$

Currently, the fundamental principle behind the securities market regulations of most jurisdictions is disclosure. ${ }^{46}$ This principle is based on the economic hypothesis that investors are rational beings. If they possess relevant information, investors could be in a position to make business decisions that are in their best interest. Hence, disclosure of relevant information, relating to specific securities and the issuers, is crucial. According to U.S. Justice Louis Brandeis, disclosure is the most effective cure of the social and industrial diseases, electric light the most efficient police officer. ${ }^{47}$ Enhancing their disclosure system requires much effort. This includes improving reporting and auditing regulation and practice and combating fraud, insider trading, and market manipulation. ${ }^{48}$

Fraud directly violates the principle of disclosure. ${ }^{49}$ Hence, securities laws universally prohibit fraud. Insider trading upsets the

42. See MARgret M. Blair, OWNERShip AND CONTROL: Rethinking CORPORATE GOVERNANCE FOR THE TWENTY-FIRST CENTURY 122 (1995).

43. O'Sullivan, supra note 36 , at 125.

44. See also Hazen, supra note 18 , at 191.

45. See LIN YIE, SECURITIES LAW 56-64 (2000).

46. COX, ET AL., supra note 13 , at 8.

47. LOUIS D. BRANDEIS, OTHER PEOPLE'S MONEY AND HOW THE BANKERS USE IT 92 (1971) ("Publicity is justly commended as a remedy for social and industrial diseases. Sunlight is said to be the best of disinfectants; electric light the most efficient policeman.").

48. LOSS \& SELIGMAN, supra note 24 at 769 (discussing fraud and duty to disclose); see also HAZEN, supra note 20 at 418 (indicating a company's disclosure requirement in self-interested transactions).

49. LOSS \& SELIGMAN, supra note 24, at 951-59. 
fairness of information disclosure and consequently damages the integrity of the financial market. This is because market participants should have equal access to the relevant information from the company that issues the securities. Corporate insiders, however, would have access to undisclosed confidential information that affects the value of the company's securities. ${ }^{50}$ They could seek to profit from the confidential information by trading their securities based on this information. This creates inequity among securities investors and also injures the company and its shareholders because the insiders profit based upon informational asymmetry.

Market manipulation is a special form of fraud. ${ }^{51}$ It is usually an attempt to drive up a stock price on the secondary market by creating demand for the stock through the dissemination of false and misleading information. ${ }^{52} \mathrm{~A}$ number of strategies could be exercised to achieve the purpose of market manipulation, including pools, churning, runs, and short selling.

Because of the important role played by the securities market in corporate development and corporate governance, countries pay great attention to securities regulation. Some countries have been trying to fully exploit the monitoring function of the securities market in order to improve the governance of their listed companies. ${ }^{53}$ China is one of the countries that have employed the supervisory functions of the securities market to assist in corporatizing its state-owned enterprises and establishing an effective governance system in its corporatized enterprises. China has also endeavoured to develop a strong legal regime over securities market and activities. ${ }^{55}$ In a span of ten years, China has enacted a securities code and a number of regulations. ${ }^{56}$

50. Insider trading in its origin refers to the corporate insider - the director, officer, employee, or associate of the corporation. Now, in same systems, it extends to a tippee the person who deals in the securities on the basis of information provided to him or her by a corporate insider. See BUTTERWORTHS BUSINESS AND LAW DICTIONARY 264, 265 (Hon. Justice Ipp et al. eds., 2d ed. 2002).

51. See COX, ET AL., supra note 13, at 691.

52. See BUTTERWORTHS, supra note 50, at 313.

53. Pinto, supra note 25, at 269-70 ; see also Alice de Jonge, Corporate Governance in a Cross-Border Environmnet: Overseas Listings of Chinese Firms, in TRENDS AND DEVElopments in CORPORATE GOVERnANCE 91-93 (Dennis Campbell ed., 2003).

54. de Jonge, supra note 53, at 91-93.

55. Id. at 97 .

56. Id. 


\section{SeCURITIES MARKET AND REgulation IN CHINA}

\section{A. The Development of Securities Market in China}

Before the 1950s, China had the largest stock market in Asia: the Shanghai Stock Exchange. ${ }^{57}$ The People's Republic of China ("the PRC") was founded in 1949. In the following thirty years, the main economic goal of the country was to establish a centrally planned economy. ${ }^{58}$ As a result, by the end of the 1950 s, stock exchanges and securities markets, together with all types of private ownership, were eliminated. ${ }^{59}$

Nearly thirty years later, in 1981, the PRC revived its securities activities. ${ }^{60}$ By then, the PRC had already given up the idea of a planned economy and initiated economic reforms aimed at establishing a market economy throughout China. ${ }^{61}$ First, the State Council issued national treasure bonds in $1981 .^{62}$ Then in 1983, a Shenzhen company issued shares for the first time in the PRC's history. ${ }^{63}$ In 1984, Shanghai Feile Acoustics made the first public share offering. In 1986, Shenyang opened the first over-thecounter market, ${ }^{64}$ which was authorized by the People's Bank of China. ${ }^{65}$ Additionally, in December 1990, the People's Bank of China authorized the establishment of two national stock exchanges: the Shanghai Stock Exchange and the Shenzhen Stock Exchange. ${ }^{66}$ The two stock exchanges were defined as non-profit legal entities. ${ }^{67}$ From the late 1980 s to the early 1990 s, a number of local stock exchanges and two national stock exchanges, Shanghai

57. See Jiangyu Wang, China's Securities Experiment: The Challenge of Globalization, at http://www.eastlaw.net/research/securities/securities-no1.htm (last accessed Nov. 12, 2005).

58. See Changuiang Li, The History and Development of China's SECuRity MARKET 28 (1998).

59. Id.

60. Zhu Sanzhu, SeCuRITIES Regulation in China 5 (2000).

61. Id. at 4-5.

62. See LI, supra note 58 , at 31 ; I. A. TOKLEY \& TINA RAVN, COMPANY AND SECURITIES LAW IN CHINA 62 (1998).

63. See LI, supra note 58 , at 53 .

64. See LI, supra note 58 , at 53 .

65. See SANZHU, supra note 60 , at $10 \&$ n. 29 .

66. See Id. at 67.

67. Jiangyu Wang, China's Securities Experiment: the Challenge of the Globalization, ch I, at http://www.eastlaw.net/research/securities/securities-intro.htm (last accessed Nov. 12, 2005). 
and Shenzhen, started operating in China. ${ }^{68}$ Different organizations, including the People's Bank of China, the State Council, the Ministry of Finance, and separate local governments regulated these stock exchanges.

Incidents relating to the operation of the stock exchanges, particularly the 810 Incident on the Shenzhen Stock Exchange in 1992, alerted the State Council to ambiguity in securities regulation and administration..$^{0}$ The State Council then clarified the regulatory authority over the securities market by establishing a specialized body to be the sole regulator of the securities market. ${ }^{71}$ Consequently, by the end of that year, the State Council established Zhipan, the China Securities Regulatory Commission (CSRC). ${ }^{72}$ The State Council intended to create a single market regulatory body. The influence, interests, and focus of this regulatory body depended on the future development of the securities market. ${ }^{73}$ But, there was strong resistance from all of the other existing regulators. ${ }^{74}$ The People's Bank, the local governments, and even the stock exchanges were not happy to have the CSRC as their sole regulator. ${ }^{75}$ As a result, for four years, the CSRC struggled to consolidate its authority, before eventually obtaining full control over the stock exchanges and the securities industry.

The first important step made by the CSRC was to gradually strengthen its influence over the securities markets. ${ }^{77}$ During 1992 to 1993, the CSRC gained extended power of investigation and

68. SANZHU, supra note 60 , at 7.

69. SANZHU, supra note 60 , at 8-10.

70. The incident happened on August 10 and was named after the date -810 . On that day, some 700,000 would be investors of a new issue packed into Shenzen to subscribe the new issue. The prescribed five million subscription forms were used up within four hours. Violent rioting resulted, as it was clear that the officials of the People's Bank of China corrupted the process of handling subscription forms. The government restored order by distributing another five million forms the next day. The incident, to a large extent, was caused by the fact that too many organizations claimed authority over the operation of securities market and activities. The situation was likely to cause confusion and corruption. See Carl E. WALter \& Fraser J. T. Howie, Privatizing China: The STOCK MARKETS AND THEIR ROLE IN CORPORATE REFORM 30 (2003).

71. TOKLEY \& RAVN, supra note 62 , at 64.

72. Id.

73. See WALTER \& HowIE, supra note 70 , at 9.

74. SANZHU, supra note 60 , at $188-89$.

75. See id.

76. Id. at 192 .

77. See WALTER \& HowIE, supra note 70 , at 9. 
enforcement. $^{78}$ The next step, during 1996, was to assume full control over the two national stock exchanges. ${ }^{79}$ Since 1997 , with the exclusion of the People's Bank of China and local governments' participation in the securities industry, the CSRC has secured and retained its status as the single regulatory power of the securities market and the securities industry in China. ${ }^{80}$ The 1999 Securities Law further clarified and affirmed the status and powers of the CSRC as the sole regulatory authority of the securities industry in China. The State Council directly overseas the CSRC. ${ }^{81}$

\section{B. Regulatory Framework of Securities Industry}

In China, the legal framework of the securities industry has developed in its own special social and historical environment. ${ }^{82}$ In other words, the evolution of securities regulation in China has followed a unique path. ${ }^{83}$ In the beginning, a number of piecemeal legal and administrative documents regulated stock exchanges. ${ }^{84}$ People hoped that the enactment of the Securities Law would supersede most, if not all, of the piecemeal regulatory documents. The 1999 Securities Law, however, has not truly lived up to its promise. In China, the Securities Law regulates the issuing and trading of shares, corporate bonds, and other such securities lawfully recognized by the State Council. ${ }^{86}$ The provisions of the 1994 Company Law and other laws and administrative regulations cover those areas outside the reach of the securities law. ${ }^{87}$ It seems that the operation of some earlier documents shall apply. ${ }^{88}$ Nevertheless, the 1994 Company Law and the 1999 Securities Law have substantially improved the earlier piecemeal situation by

78. See WALTER \& HowIE, supra note 70 , at 9.

79. Id. at $9-10$.

80. See id. at 10; Gao Xiqing, Some Regulatory Issues of the PRC Securities Market, in: CHINA 2000: EMERGING INVESTMENT, FUNDING AND ADVISORY OPPORTUNITIES FOR A NEw CHINA, ONLINEBOOKS, at http://www.asialaw.com/bookstore/china2000/ chapter01.htm (Nov. 12, 2005).

81. See SeCurities LAw of THE PeOple's Republic of China arts. 7, 166

(P.R.C.), available at http://www.csrc.gov.cn [hereinafter SECURITIES LAw].

82. SANZHU, supra note 60 , at 8 .

83. See id.

84. See TOKLEY \& RAVN, supra note 62, at 66; SANZHU, supra note 60, at 207.

85. See SANZHU, supra note 60 , at 13.

86. SECURITIES LAW, supra note 81 , art. 2.

87. Id.

88. SANZHU, supra note 60 , at $79-80$. 
establishing a unified regulatory framework over China's securities industry.

Today, the sources of securities regulation include the following:

- The 1994 Company Law provides provisions governing the establishment and operation of stock companies; it also sets provisions over the conduct of companies operating on securities markets. For example, it forbids the conduct of short-swing trading and the conflicts of interest of company directors. ${ }^{90}$

- The 1999 Securities Law regulates the establishment and operation of stock exchanges and brokering firms; issuing and trading of securities; and securities registration and clearing institutions. ${ }^{91}$ The 1979 Criminal Code deals with corporate and securities market offences. ${ }^{92}$

- Special Regulations of the State Council; it is noteworthy that the Securities Law only applies to the issuing and trading of shares, bonds, and other securities recognized by the State Council within China. It applies neither to shares listed abroad, nor to shares of Chinese companies reserved for foreign investment. ${ }^{93}$ Neither does the Securities Law apply to government bonds. The State Council regulates the above exempt securities.

- The 1997 Methods of Administrating Securities Investment Funds are other relevant State Council regulations.

- Ministry Rules refer to relevant administrative rules and regulations over the securities industry; they were enacted on behalf of some ministries and commissions, including the CSRC, directly under control of the

89. Id. at 103.

90. Such regulations are mainly contained in COMPANY LAW OF THE PEOPLE'S REPUBLIC OF CHINA, chs. 4, 5 (1994), available at http://www.cclaw.net/download/ companylaw.asp.

91. SECURITIES LAW, supra note 81, arts. 5-7.

92. Such provisions are mainly contained in CRIMINAL CODE OF THE PEOPLE'S REPUBLIC OF CHINA, chs. 3, 4 (1979).

93. These refer to $B$ shares, $H$ shares, $L$ shares and $N$ shares. $B, H, N, L$ shares are RMB denominated shares, but should be purchased by foreign or domestic investors by using foreign currency. 
State Council.

- Finally, Self-Regulation, including rules of selfregulation made through the Articles of Association of China Securities Association, business rules of the Shanghai and Shenzhen stock exchanges, represent the final set of relevant regulations."

By taking a close look at these regulations, one could see that the Securities Law and the Company Law primarily regulate the issuance of securities. These two laws also regulate shares and stock companies. Furthermore, insider trading, market manipulation, and disclosure are largely regulated by the Securities Law.

It is interesting to note that a large part of the Chinese Securities Law focuses on the establishment and operation of stock exchanges, stock brokering companies, and market intermediaries. ${ }^{95}$ Because of this, Chinese Securities Law trespasses upon the territory of Company Law. ${ }^{96}$ Such an overlap seldom occurs in the securities laws of western countries."

The enactment of the Company Law in 1994 was a milestone in China's enterprise reform. ${ }^{98}$ Notably, the Company Law affirmed the policy of developing a market economy. ${ }^{99}$ Since the implementation of the law, China has experienced an unprecedented wave of corporatization and privatisation.

However, ongoing corporate practice revealed some aspects of inefficiency in the Company Law, even from the very beginning of its enactment. ${ }^{100}$ Since the enactment of the Company Law in 1994, scholars and practitioners wanted to amend the Company Law. ${ }^{101}$ This is because the Company Law leaves many gaps or loopholes to be filled..$^{102}$ Many issues are not clearly addressed by

94. See XIANYI ZENG, SECURITIES LAW 26-28 (2000).

95. SECURITIES LAW, supra note 81 , arts. 5, 6.

96. Jiangyu Wang, China's Securities Experiment: The Challenge of Globalization, at http://www.eastlaw.net/research/securities/sec2g.htm (last accessed Nov. 12, 2005).

97. Id.

98. Anna M. Han, China's Company Law: Practicing Capitalism in a Transitional Economy, 5 PAC. RIM L. \& POL'Y J. 457, 459 (1996).

99. SANZHU, supra note 60 , at 88-89.

100. Han, supra note 98 , at 460 .

101. See Xiqing, supra note 80; see also Walter Hutchens, PRC Amends Company Law and Securities Law, WalterHutchens.com (Aug. 30, 2004), at http://www.smith.umd.edu/ faculty/whutchens/2004/08/prc-amends-company-law-and-securities.html

102. SONJA OPPER, ET AL., THE POWER STRUCTURE IN CHINA'S LISTED COMPANIES: THE COMPANY LAW AND ITS ENFORCEMENT 26 (H.K. Institute of Econ. 
the Company Law, such as directors' fiduciary duties, classification of shares, shareholders' derivative actions, and class actions. ${ }^{103}$ Nevertheless, the Company Law 1994 has stood for ten years without any significant amendments. ${ }^{104}$ Within those ten years, China increased the role of the CSRC and reinforced securities legislation. ${ }^{105}$ Consequently, the CSRC has become very active in effectively regulating listed companies to improve corporate governance.

\section{The Regulatory Activities of China Securities Regulatory Commission over Corporate Governance}

Since its establishment, the CSRC has been given an increasingly active role in regulating the issuance and trade of securities and the operation of stock exchanges. ${ }^{106}$ For example, the CSRC enacted the Announcement of Prohibition of Market Manipulation and the Provisional Rules of Prohibition of Entry into the Securities Market. ${ }^{107}$ In October 2003, the CSRC enacted five more legal documents, including:

- The Disclosure Standard of Securities Companies Issuing Shares to Particular Investors; ${ }^{108}$

- The Standard of Reports on Assessing the Credibility and Ranks of Securities Companies; ${ }^{109}$

- The Standard of Application Form for Issuance of Securities by Securities Companies; and ${ }^{110}$

- The Standard of Prospectus of Securities Companies, and the Standard of Announcement of Being Listed. ${ }^{111}$

Additionally, just one month before, on August 29, 2003, the CSRC promulgated the Provisional Methods of Administrating the

and Bus. Strategy Working Paper No. 1039, 2002).

103. See Xiqing, supra note 80.

104. Walter Hutchens, Major Revision to PRC Company Law Moving Forward, Walter Hutchens' Blog (Feb. 25, 2005), at http://www.rhsmith.umd.edu/faculty/whutchens/ 2005/02/major-revision-to-prc-company-law.html.

105. See generally Han, supra note 98 , at 457.

106. See Xiqing, supra note 80.

107. The Announcement of Prohibition of Market Manipulation was promulgated in 1996, and the Provisional Rules of Prohibition of Entry into the Securities Market was promoted in 1997.

108. See generally http://gbcode.tdctrade.com/gb/my.tdctrade.com/airlaws/ index.asp? area $=01 \& c t=08 \& s t=0803$ (last accessed Nov. 12, 2005).

109. See generally Id.

110. See generally Id.

111. See generally Id. 
Securities of Securities Companies. ${ }^{112}$

The regulatory power of CSRC has trespassed into the traditional territories of both the Company Law and Securities Law. ${ }^{113}$ This is particularly true in the area of corporate governance. ${ }^{114}$ For instance, because the Company Law does not provide detailed provisions on corporate governance, the CSRC has endeavoured to fill this gap. In 2001, the CSRC produced the Guidelines for Introducing Independent Directors to the Board of Directors of Listed Companies. ${ }^{15}$ Then in 2002, it promulgated the Code of Corporate Governance for Listed Companies. ${ }^{16}$ Since July 2003, the CSRC has further required that at least one third of the members of the board of directors be independent directors. ${ }^{117}$ Furthermore, the CSRC also organized training classes for independent directors. ${ }^{11}$

Furthermore, the CSRC stipulated detailed requirements for shareholders' general meetings in listed companies. ${ }^{119}$ According to the Suggestions on Regulating the General Meetings of Listed Companies 2000, listed companies should lodge a report with the stock exchanges to explain their reasons for not holding an annual general meeting - within the prescribed timeframe. ${ }^{120}$ This is important because stock exchanges may delist a company that fails to hold annual general meetings on time without a reasonable excuse. ${ }^{121}$ Thus, the CSRC further suggests that the board of

112. Freshfields Bruckhaus Deringer, China Investment Banking \& Financial Services Legal Alert, at http:/www.freshfields.com/places/china/fsnews/pdfs/compendium.pdf (last accessed Nov. 12, 2005).

113. Tong Lu, Corporate Governance in China, China Center for Corporate Governance 8 , at http://www.iwep.org.cn/cccg/pdf/Corporate $\% 20$ Governance $\% 20$ in $\% 20$ China $\% 20 \%$ 20Prof.pdf (last accessed Nov. 12, 2005).

114. Id. at 8-9.

115. China Sec. Reg. Comm'n, Code of Corporate Governance for Listed Companies in China (Jan. 7, 2001) at http://www.csrc.gov.cn/en/jsp/ detail.jsp?infoid=1061968722100\& type=CMS.STD (last accessed Nov. 12, 2005) [hereinafter Code of Corporate Governance].

116. China Securities Regulatory Commission, Guidelines for Introducing Independent Directors to the Board of Directors of Listed Companies at http://www.csrc.gov.cn/en/jsp/detail.jsp?infoid=1061947864100\&type=CMS.STD [hereinafter Guidelines].

117. Guidelines, supra note 116.

118. Lu, supra note 113 at 7 .

119. Id. at 4.

120. See China Securities Regulatory Commission, Suggestions on Regulating the General Meetings of Listed Companies, art. 3 (2000).

121. See China SECuRITIES REgulatory COMmission, Suggestions on Regulating the General Meetings of Listed Companies, art. 3 (2000). 
directors invite securities lawyers to attend the general meetings and publish their expert opinions on the validity of the procedures of the meeting, and the qualifications of the attendees and shareholders who called the meeting. ${ }^{122}$ It is also suggested that the board may also invite public notaries to attend the meeting. ${ }^{123}$

Apart from independent directors and the detailed requirements on general meetings, the CSRC vigorously promoted greater disclosure by listed companies. Listed companies are required to publish Half-Yearly Reports ${ }^{124}$ and Annual Reports. ${ }^{125}$ In addition to these periodical reports, listed companies must also make continuous disclosure. ${ }^{126}$ Whenever a major issue occurs, a listed company must announce it publicly. ${ }^{127}$ The method of disclosure is to publish information or documents in specified newspapers, periodicals, and gazettes. In addition, information should be made available for public inquiry at the company and the stock exchange. ${ }^{128}$ Recently, the CSRC has published a set of five documents relating to disclosure. ${ }^{129}$ These documents provide detailed requirements on the preparation of a prospectus and expert report, and the standard of disclosure..$^{130}$

The CSRC has the power to delist non-profitable or poorly performing companies. ${ }^{131}$ The CSRC may give the companies an opportunity to improve their performance before delisting them. ${ }^{132}$ In the meantime, the CSRC would give warnings to potential investors in those companies. ${ }^{133}$ In China, poorly performing or non-profitable companies are formally labeled as either "PT Companies" or "ST Companies." ${ }^{134}$ PT means Particular Transfer, which indicates that the companies have made losses in the past

122. Id. art. 3.

123. Id. art. 7.

124. SECURITIES LAW, supra note 81 , art. 60.

125. Id. art. 61.

126. See id. art. 62.

127. Id.

128. Id. art. 64 .

129. See generally http://gbcode.tdctrade.com/gb/my.tdctrade.com/airlaws/ index. asp? area $=01 \& \mathrm{ct}=08 \& \mathrm{st}=0803$ (last accessed Nov. 12, 2005).

130. Id.

131. Poor performers face delisting, at http://english.people.com.cn/english/200103/22/ eng20010322_65672.html (last updated Mar. 22, 2001).

132. Id.

133. Id.

134. Id. 
three consecutive years. ${ }^{135}$ ST means Special Treatment, which indicates that the companies have made losses in the past two consecutive years. ${ }^{136}$

In 2001, the CSRC and the State Economic and Trade Commission jointly initiated a program inspecting the establishment and development of a model corporate governance system in listed companies. ${ }^{137}$ The aims of the inspection scheme were to gain a clear understanding of the current situation of listed companies in developing their modern corporate mechanisms, to identify problems, and to propose effective solutions. ${ }^{138}$ The Chinese authorities expected that the program would further promote the establishment of a modern corporate system in listed companies, protect the rights of investors, and advance the healthy development of the securities market. ${ }^{139}$ The matters to be inspected included:

- whether controlling shareholders influenced staff, or financial arrangements;

- the appropriation of funds of listed companies by controlling shareholders;

- whether controlling shareholders interfere in the decision-making processes relating to the appointments of directors, supervisors, managers, and other senior officers, and the business affairs of the listed companies;

- matters relevant to enterprise reforms;

- operation of the general meeting, the board of directors and the supervisory board;

- the use of funds raised on the securities market; and

- statements in periodical and interim reports. ${ }^{140}$

The inspection took six months and was carried out in three phases. The first phase was the Self-Inspection Phase that lasted about two months. The second phase was the Emphasis Inspection Phase. In this phase, the branches of the CSRC and the

135. Id.

136. Id.

137. See China Sec. Reg. Comm'n, Code of Corporate Governance at http://www.csrc.gov.cn/en (last accessed Nov. 12, 2005).

138. Id.

139. See China Sec. Reg. Comm'n, Announcement of Carrying out the Inspection of the Development of Modern Corporate System in Listed Companies 2002 at http://www.csrc.gov.cn/en (last accessed Nov. 12, 2005).

140. Id. 
Commission of Economy and Trade randomly selected some listed companies as targets of inspection. And finally, the CSRC and the Commission of Economy and Trade analyzed and concluded upon the outcomes of the inspection. ${ }^{14}$

The Chinese Company Law and Securities Law do not grant the right of class actions and provide investors with few civil remedies. ${ }^{142}$ Recently, the High Court of China ruled that investors could sue the company or the directors of the company, if the investigation of the CSRC found that there were fraudulent activities. ${ }^{143}$ Now, some officials of the CSRC are calling for the introduction of Class Actions. ${ }^{144}$

From these discussions, one can see that the CSRC has been playing an increasingly active role in promoting the practice of sound corporate governance. Its important role in China's corporate and securities systems deserves a closer look.

D. A Closer View of the China Securities Regulatory Commission (CSRC)

It is interesting to note that the CSRC only has the status of a ministry in China. ${ }^{145}$ At present, it does not exactly fit in the description of a securities regulatory authority under securities law. The wording in securities law implies that a securities regulatory authority should not be a public institution, but only a ministry or a commission under direct control of the State Council. ${ }^{146}$ However, in reality, the CSRC is clearly a public institution. $^{147}$

The CSRC is different from the Australian Securities and Investments Commission (ASIC) and the Securities and Exchange Commission (SEC) in the United States. In Australia, the ASIC is a government body and administers Australian corporations law. ${ }^{148}$ Under the supervision of the ASIC, the Australian Stock

141. Id.

142. See Wenhai Cai, Private Securities Litigation in China: Of Prominence and Problems 13 COLUM. J. ASIAN L. 135, 143-48 (1999).

143. Susan V. Lawrence, Ally of the People, FAR E. ECON. REV., May 9, 2002, at 26.

144. Bei Hu, China Urged to Adopt Class Action Suits, S. CHINA MORNING POST, Nov. 21,2002 , at 1 .

145. China Sec. Reg. Comm'n, About Us, at http://www.csrc.gov.cn/en/ homepage/about_en.jsp (last accessed Nov. 12, 2005).

146. See SECURITIES LAW, supra note 81 , at 210.

147. Id. art. 172.

148. Australian Sec. and Inv. Comm'n (ASIC), ASIC at a Glance, at http://www.asc.gov.au (last accessed Nov. 12, 2005); ASIC, The Laws ASIC Administers, at http://www.asc.gov.au (last accessed Nov. 12, 2005). 
Exchange produces its own listing and business rules. ${ }^{149}$ If there is a breach, the stock exchange itself decides whether to delist a company. ${ }^{150}$ In the United States, the SEC administers the stock exchanges, has authority to administer and supervise securities activities in that country, and is given extended power of investigation. ${ }^{151}$ Under the administration and supervision of the SEC, stock exchanges, clearing houses and the National Association of Securities Dealers also make their own rules of selfregulation. ${ }^{152}$

In China, however, the CSRC deals with the market more directly. ${ }^{153}$ For instance, it retains the power of delisting poorly performing companies and it stipulates detailed requirements on general meetings and disclosure. ${ }^{i 54}$ In a sense, its regulatory power may have eroded some traditional territory of the Company Code and Securities Code, as well as some territory of self-regulation of the stock exchanges.

There are basically three types of securities regulatory practice. The first type is the Australian model discussed above. The second type of securities regulatory practice is the U.S. style, with a centralized regulatory authority (the SEC) with extensive power of administration and regulation over securities activities and operation of stock exchanges. ${ }^{155}$ The third type of securities regulatory practice we shall look at is the German style. In Germany, banks play an important role in regulating securities activities. ${ }^{156}$ Banks are members of stock exchanges, essentially monopolizing the stock broking business ${ }^{157}$ and underwrite most

149. See Alan Shaw \& Paul von Nessen, The Legal Role of the Australian Securities Commission and the Australian Stock Exchange, in SECuRITIES REGULATION IN AUSTRALIA AND NEW ZEALAND 163-85 (Gordon Walker ed., 1998).

150. Id. at 188 .

151. U.S. Sec. \& Exch. Comm'n (SEC), The Investor's Advocate: How the SEC Protects Investors and Maintains Market Integrity, at http://www.sec.gov/about/whatwedo.shtml (last accessed Nov. 12, 2005).

152. Id.

153. See SANZHU, supra note 60 , at 51 (2000).

154. See id. at 51-52, 192.

155. See Generally, the Securities and Exchange Commission, the Investor's Advocate: How the SEC Protects Investors and Maintains Market Integrity, at http://www.sec.gov/about/whatwedo.shtml (last updated Aug. 19, 2005).

156. See YUWA WeI, COMPARATIVE CORPORATE Governance: A CHINESE PERSPECTIVE 142 (2003).

157. See Brian R. Cheffins, Mergers and Corporate Ownership Structure: The United States and Germany at the Turn of the 20th Century, 51 AM. J. COMP. L. 473, 498 (2003). 
securities issued by companies. ${ }^{158}$ Consequently, Germany has comparatively relaxed rules of disclosure. ${ }^{159}$ As sophisticated investors, banks have the means and skills to obtain necessary commercial information. ${ }^{160}$

China presents a different type of securities regulatory practice from those three classic types. In the past decade, China persistently strengthened the power of the CSRC. ${ }^{161}$ Based on this, many may believe that the country is going in the direction of the U.S. style of corporate governance by building a strong securities regulatory regime. China's situation, however, is not exactly the same as that of the United States. Historically, the reason for a strengthened securities regime in the United States is that the states pre-empted the regulatory power over corporations. ${ }^{162}$ Building a robust securities legal regime is an effective strategy of federal control over U.S. corporate and securities systems. ${ }^{163}$ China, on the other hand, is motivated by contrasting factors regarding promotion of the securities market and securities regulation.

The introduction of modern corporate mechanisms into the Chinese enterprise system is the essential component of the economic reform package. As mentioned above, since 1996, the pace of corporatization in China has accelerated. An important objective of the Chinese authority is to encourage companies to be listed on the securities market, thus putting companies under the supervision of the market. ${ }^{164}$ In doing so, the authority hopes that the process of establishing a modern corporate governance system in these enterprises can be sped up. ${ }^{165}$ In this sense, the CSRC acts as a separate leverage for accelerating enterprise reform in China.

The CSRC has aggressively promoted sound corporate

158. See id.

159. See Anupama J. Naidu, Was Its Bite Worse Than Its Bark? The Costs SarbanesOxley Imposes on German Issuers May Translate into Costs to the United States, 18 EMORY INT'L L. REV. 271, 282 (2004).

160. See id. at 282 n. 75.

161. See SANZHU, supra note 60, at 8-9.

162. See WEI, supra note 156 , at 134-35.

163. See id. at 135.

164. See generally Tong Lu, Corporate Governance in China, China Center for Corporate Governance $8, \quad$ at http://www.iwep.org.cn/cccg/pdf/ Corporate $\% 20$ Governance $\% 20 \mathrm{in} \% 20$ China $\% 20 \% 20$ Prof.pdf (last accessed Nov. 12 , 2005).

165. See generally Wu Zhipan \& Bai JiAnJun, LAW AND PRACTICE OF SECuRITIES TRANSACTION I-VIII (2000) (hereinafter LAW AND PRACTICE). 
governance that assists Chinese companies to withstand scrutiny. ${ }^{166}$ The CSRC developed in China's special social and economic context which has tightly linked the development of the CSRC to China's enterprise reform. ${ }^{167}$

Hence, the CSRC plays an extremely important and special role in China's enterprise reform. It is expected to continue to vigorously bring changes and improvement to China's corporate and securities systems. The CSRC Vice Chairperson, Laura Cha, pronounced: "For our part, the CSRC is committed to be a proactive regulator in fostering corporate governance, in enforcing our rules, in safeguarding the integrity of our markets, and in championing the rights of our investors."

The current development of the securities legal regime and the securities' regulatory authority in China suggests that the status of the CSRC as the centralized and powerful regulatory and administrative authority over the securities market is firmly established. How far it will go in that direction remains to be seen. The activities pursued by the CSRC brought and will inevitably bring further significant influence to the law and practice of corporations and securities in China.

\section{THE FUTURE}

\section{A. Markets Have To Be Regulated by Market Rules}

China's securities practice emerged from the economic reforms of the 1980 s. $^{169}$ By 2000 , the Shanghai Stock Exchange was one of the best performing houses in the world. ${ }^{170}$ In general, the Chinese capital market fared reasonably well before the plunge of July 2001. ${ }^{171}$ The situation went from bad to worse. The government plans of raising social securities funds have been

166. See generally CSRC, Corporate Governance, at http://www.csrc.gov.cn/ cn/jsp/third.jsp?path=ROOT\%3ECN\%3E\%B7\%A8\%C2\%C9\%B7\%A8\%B9\%E6\%3E \%B2\%BF\%C3\%C5\%B9\%E6\%D5\%C2\%3E\%B9\%AB\%CB\%BE\%BC\%E0\%B9\%D $\mathrm{C}$ (last accessed Nov. 12, 2005).

167. See generally Id.

168. Laura M. Cha, The Future of China's Capital Markets and the Role of Corporate Governance, Luncheon Speech at China Business Summit (April 18, 2001), at http://www.csrc.gov.cn/en/jsp/detail.jsp?infoid=1061948105100\&type=CMS.STD.

169. See CHANGJIANG LI, THE HISTORY AND DEVELOPMENT OF CHINA'S SECURITY MARKET 28 (1998).

170. See CHEN QINGBO, SECURITIES ENGLISH 148 (2003).

171. See DEHUAN, supra note 3, at 6. 
under threat, and many private companies have been adversely affected. ${ }^{172}$

By September 2001, the trading value of the Shanghai and Shenzhen stock exchanges accounted for $51.26 \%$ of GDP. ${ }^{173}$ Unlike the developed markets, however, the Chinese capital market fluctuates irregularly, and the volatility of the market follows a drastic pattern. From 1990 to mid-2001, the Chinese securities market soared to an historic high followed by several periods of a flat market. ${ }^{174}$ Since July 2001, the market could be classified as a bear market. ${ }^{175}$

In the past, the Chinese government produced a number of interventional strategies to control the flux on the securities market and to avoid crises that could devastate the market as a whole. When the market soared to an unprecedented high, the government suspended the issuance and trade of new shares to prevent the formation of an investment bubble. ${ }^{176}$ Adjusting financial policies was another way of intervening in the securities market. ${ }^{177}$ For example, in 1996 , the government cut the interest rate twice and the market reacted positively. ${ }^{178}$ It was estimated that around $¥ 500$ million flowed into the securities market as the result of interest rate reductions. ${ }^{179}$

The government also tried to use the media to cool down an overheated market. This was successful in some cases, but not always. For instance, in 1994, the market skyrocketed. ${ }^{180}$ The government sensed the danger of a market crash and released a large quantity of news in the press to warn investors. ${ }^{181}$ Investors, however, did not react to the warning and share prices continued to soar. ${ }^{182}$ Eventually, the market crashed spectacularly, dropping $70 \%$ from its peak. ${ }^{183}$ Such a sharp fall had rarely been seen in the

172. See the Shangzheng fluctuation history, at http://www.sse.com.cn/ sseportal/ps/zhs/ggxx/zsjbxx.jsp?indexName $=\&$ indexCode $=000010$ (last updated Jun. 18, 2002).

173. See DEHUAN, supra note 3, at 4.

174. See supra 172.

175. See Id.

176. See CHEN, supra note 1 , at 118 .

177. See CHEN, supra note 1 , at 154 .

178. Id., at 154 .

179. Id. at 154 .

180. See Id. at 118,138 .

181. See Id. at 138.

182. See Id. at 118.

183. Id. 
modern world. ${ }^{184}$ In contrast, the Chinese government successfully intervened the feverish speculation in shares of Shenzhen Development Bank (SDB) through the media in $1996 .{ }^{185}$

Since mid-1996, the wild trade in shares of SDB catalyzed a bull market in both the Shanghai and Shenzhen stock exchanges. ${ }^{186}$ Concerned about the ultimate outcome, the government decided to intervene and issued a warning through a "special correspondent" in a People's Daily editorial on December $16 .{ }^{187}$ Due to the political status of People's Daily and the historically significant role played by such an editorial to China's political and economic life, not many investors could afford to ignore the message conveyed in the editorial. ${ }^{188}$ Within three weeks, the Shezhen market was down $30 \%{ }^{189}$

Generally speaking, government intervention was an effective means of control over the volatility of China's securities market in the 1990s. It seems, however, that government intervention is less likely to achieve the goal of control in China today. Since the bear market started in 2003, Chinese authorities have sought to control the fall in the market. ${ }^{190}$ But intervention has proved to have little effect. ${ }^{191}$ For example, one strategy adopted was to limit the size of new offerings. ${ }^{192} \mathrm{~A}$ listing application would not be approved if the company sought to sell shares at a price of more than twenty times its earnings. ${ }^{193}$ The strategy proved to be unsuccessful. Reports found that many well-performing companies decided not to issue new shares and a significant number of promising private companies moved to Hong Kong, as its market looked more attractive. $^{194}$

This suggests that it is time for the Chinese to work through the problems in the securities market and find solutions to improve market performance. At present, the main problems in the securities business include undue government intervention,

184. See generally Id.

185. Id. at 163 .

186. See generally CHEN, supra note 1 , at 163 .

187. See CHEN, supra note 1, at 162-164.

188. See WALTER \& HOWIE, supra note 70, at 212.

189. See id. at 212; see also CHEN, supra note 1, at 161-163.

190. See generally Wei, supra note 156 .

191. Id.

192. Id.

193. See DEHUAN, supra note 3, at 4 .

194. See Id. at 149. 
lack of regulatory leverage, and poor corporate governance. ${ }^{195}$ Excessive government interference is a proven problem that burdens the securities business in China. ${ }^{196}$ Theoretically, China's system of control over the securities market and its transactions has become a combination of governmental supervision and selfregulation in the securities markets. In practice, governmental supervision is the paramount influence. ${ }^{197}$ Consequently, the selfregulatory function of the stock exchanges remains marginal. ${ }^{198}$ For example, currently, the authority to investigate misconduct of listed companies is given to the government body, the CSRC, not the stock exchanges. ${ }^{199}$ As a result, the stock exchanges are unable to swiftly impose liability on companies that have uttered misstatements. ${ }^{200}$

Furthermore, the supervisory functions of the CSRC and the stock exchanges are not clearly divided. The CSRC, in practice, has considerable power to intervene in the securities market and its transactions. ${ }^{201}$ Moreover, to be eligible to be listed on a stock exchange, a company must obtain approval from the CSRC. ${ }^{202}$ In other words, a stock exchange does not have the final say relating to whether a company should be admitted into the stock exchange. Nevertheless, the stock exchanges provide listing requirements, and companies have to meet these requirements to qualify to trade on their stock exchanges.

The stock exchanges are closer to the securities market than any government body could be, and are better placed to receive market information. Hence, it is desirable to fully implement a self-regulatory capacity within China's stock exchanges. Furthermore, the self-regulation approach is more acceptable and business friendly to listed companies. In short, China needs to determine how to enhance the self-regulatory function of its stock

195. See Id. at 200-203.

196. Id. at 201.

197. Id. at 201.

198. Id. at 201.

199. Id. at 201.

200. Id. at 201.

201. Id.

202. See SECURITIES LAW, supra note 81 , art. 10 ("Public offers of securities shall meet the conditions prescribed in laws and administrative regulations and shall, in accordance with law, be reported to the securities regulatory authority under the State Council or the department authorized by the State Council for verification or examination and approval. No unit or individual may make a public offer of securities if the same has not been verified or examined and approved according to law."). 
exchanges.

The lack of efficient regulation over the securities market and business is another serious problem that is hindering the healthy development of the securities market. ${ }^{203}$ China does not have detailed legislation regulating securities transactions, protecting investors and supervising securities services. The current Securities Law provides general principles relating to securities markets and transactions, but it leaves many issues to be remedied. These loopholes still allow dealings on the market and increase difficulties in enforcing the Securities Law and other regulations. For example, the Securities Law does not provide civil remedies that could be made available to victims of insider trading. ${ }^{204}$ It only provides that the insider may receive a fine or face imprisonment, and that illegal profits are to be confiscated. ${ }^{205}$ Regarding disclosure, the law states that a company has the duty to make complete and actual disclosure. ${ }^{206}$ It seems, however, that the law neglects to require companies to make timely disclosuredisclosure within a prescribed time. ${ }^{207}$ Because of gaps in legislation, market misconduct is still not dealt with efficiently. ${ }^{208}$ Efforts need to be made to further complete the securities legislation.

It is noteworthy that in China, many incidents of market misconduct are connected to poor corporate governance. The volatility of the securities market is frequently associated with corporate governance problems. ${ }^{209}$ This distinguishes the Chinese securities market from more mature markets. Many listed Chinese companies still experience insider control problems. ${ }^{210}$ China, insider control problems usually result from the shareholding structure in its state-controlled listed companies. ${ }^{211}$ Most listed companies are corporatized, state-owned, or controlled enterprises with the state being the dominant shareholder. ${ }^{212}$ Minority

203. See CHEN, supra note 1 , at $138,199$.

204. See SECURITIES LAW, supra note 81, art. 183.

205. See id.

206. See SECURITIES LAW, supra note 81, art. 59.

207. See Li ShIPPING, CASE STUdies OF EsSEnTIAL IsSuES CONCERNING THE SECURITIES LAW 47-48 (2001).

208. See SECURITIES LAW, supra note 81, Section 3.

209. See DEHUAN, supra note 3, at 215-217.

210. DEHUAN, supra note 3, at 216.

211. Id.

212. $I d$. 
shareholders in those companies do not have the power to change the management nor the boards. ${ }^{213}$ The state, as the dominant shareholder, has to rely on its agents to exercise its shareholders' rights. $^{214}$ The directors of these companies are appointed by the relevant authorities or state agents. ${ }^{215}$ There are opportunities for directors to entrench themselves in their positions and make themselves de facto owners of the companies. ${ }^{216}$ As insiders, once they seize control of the company, they may pursue private goals other than maximizing shareholders' interests. For example, insiders may excessively increase their remuneration and other private benefits without fear of intervention from other shareholders. Moreover, members of the supervisory board in such companies are also insiders. ${ }^{217}$ Such a supervisory board cannot efficiently exercise supervision over its management. In many cases, poor corporate governance can lead to misconduct on the securities market, and insider trading has become the typical example. ${ }^{218}$ Insiders deal with the securities of their own companies based on undisclosed, price sensitive information, or supply the information to other parties.

Recent years have seen the emergence of a few privately owned and listed companies in China. ${ }^{219}$ Such companies are usually in the hands of a single individual or family. In such a company, the dominant shareholder may obtain excessive personal profit by exploiting minority shareholders. ${ }^{220}$ It appears that both state-controlled companies and individual or family-controlled companies have trouble in adhering to the ethical practice of corporate governance. ${ }^{221}$ Improving corporate governance of listed companies has become the Chinese government's most imperative task in business.

China has much to do to improve its securities practice and regulation. Thus, its securities system is still in the process of development. How China will shape its securities regime is an

213. Id.

214. Id.

215. Id.

216. Id.

217. Id.

218. Id. at 217

219. See generally How large is China's private sector? at http://www.flonnet.com/fl2221/stories/20051021001708700.htm (last updated Oct. 08, 2005)

220. See DEHUAN, supra note 3, at 217.

221. See Id. 
issue stimulating much interest.

Different jurisdictions have adopted different systems of securities regulation. The divergence of securities regulation and practices illustrates that different social, political, economic, and historical environments foster different systems of securities' regulation and practice, suitable to the specific circumstances. Some differences merely lie in technical divergences. Experiences under the different systems provide valuable resources for the Chinese to use for reference in order to find their own path of developing an efficient fund-raising mechanism for their newly corporatized state-owned enterprises and their fledgling private enterprises. At the moment, some people conjecture that China is following suit with the United States, while others predict that the German-Japanese bank-based model will finally be accepted by the Chinese.

\section{B. Will China Follow the U.S. Path?}

Current U.S. regulation of the securities market can be traced to ancient England. ${ }^{222}$ However, in modern days, the UK securities market is not the largest. ${ }^{223}$ The privilege of maintaining the largest securities market and the most influential securities regulatory regime is claimed by the United States. ${ }^{224}$

Current securities regulation in the United States is the result of long-term development and painful experience. ${ }^{225}$ In the beginning, the U.S. securities market was not adequately regulated. $^{226}$ After World War I, huge amounts of money were being pumped into the securities market. ${ }^{227}$ Consequently, share prices were pushed to an historical high and created a "bubble" in securities investment. ${ }^{228}$ The bubble burst, numerous corporations collapsed, and the whole country slipped into economic depression. $^{229}$ The Securities Act of 1933 and the Securities

222. Loss \& SELIGMAN, supra note 24 , at 1.

223. Amir Licht, David's Dilemma: A Case Study of Securities Regulation in a Small Open Market, 2 THEORETICAL INQUIRIES L. 673, 684 (2001).

224. Id.

225. See Joel Seligman, The Transformation OF Wall Street: A History of THE SECURITIES AND EXCHANGE COMMISSION AND MODERN CORPORATE FINANCE (1995).

226. See id. at 349 .

227. See id. at 1-2.

228. See id. at 2-3.

229. See CASKEY, supra note 23 , at 8 . 
Exchange Act of 1934 were enacted primarily to bring activities on the securities market under close control. ${ }^{230}$

The Securities Act of 1933 focuses markedly on public distribution of securities. ${ }^{231}$ It requires companies to disclose necessary information when issuing securities to the public. ${ }^{232}$ The Securities Exchange Act of 1934 gives the SEC power to regulate all aspects of the securities industry, as well as to investigate and punish illegal dealings. ${ }^{233}$ It regulates insiders' transactions in securities, proxy solicitations, and tender offers; provides antifraud provisions; and prohibits manipulation in securities dealings. ${ }^{234}$

One of the most distinctive features of U.S. securities regulation is the development of rigorous securities laws and rules. ${ }^{235}$ The securities market and its transactions are under close regulatory surveillance ${ }^{236}$ and a strong legal regime, separate from the Corporations Code, exists over securities. ${ }^{237}$ Historically, the power of making corporations law has been entrenched in state jurisdictions due to constitutional implications. ${ }^{238}$ In efforts to attract more corporations to their own states, the states initially raced to produce more relaxed rules for corporate operation in their jurisdictions. ${ }^{239}$ The federal attempt at securities regulation followed. ${ }^{240}$ The question for the states was whether they were willing to impose stringent securities regulation on corporations in their jurisdiction at the risk of driving corporations to incorporate elsewhere. ${ }^{241}$ For regulating securities effectively, it was necessary to establish a strong securities regulatory regime at the federal

230. See SEC, The Laws that Govern the Securities Industry, at http://www.sec.gov/about/laws.shtml (last accessed Nov. 12, 2005).

231. See DaVid L. RATNER \& ThOMAS LEE HAZEN, SECuRITIES Regulation IN A NUTSHELL 34 (2002).

232. Securities Act of 1933, 15 U.S.C. \$\$ 77a-781ll (2004); see also SEC, supra note 230.

233. Securities Exchange Act of 1934, 15 U.S.C. $\$ \S 78 \mathrm{a}-78 \mathrm{~mm}(2004)$.

234. Securities Exchange Act of 1934, 15 U.S.C. $\$ \S 78 \mathrm{a}-78 \mathrm{~mm}(2004)$.

235. See AlFRed F. CONARD, CORPORATIONS IN PERSPECTIVE 39 (1976).

236. Id. at 42.

237. Id. at 46 .

238. Id. at $22,41-42$.

239. Liggett Co. v. Lee, 288 U.S. 517, 558-59 (1933) (Brandeis, J., dissenting) (noting that "[c]ompanies were early formed to provide charters for corporations in states where the cost was lowest and the laws least restrictive. The states joined in advertising their wares. The race was one not of diligence but of laxity.").

240. CONARD, supra note 235, at 22.

241. See id. at 42. 
level. ${ }^{242}$ Accordingly, the Securities Act of 1933 and the Securities Exchange Act of 1934 became federal law.

The spirit of U.S. securities laws is disclosure. ${ }^{243}$ The Securities Act of 1933 requires the issuer of securities to timely file a registration statement with the SEC before issuing new securities. ${ }^{244}$ Disclosure is made by including relevant statements in the prospectus and registering those statements with the SEC. ${ }^{245}$ The Securities Exchange Act of 1934 requires periodical reports from the issuers, ${ }^{246}$ as well as requiring the issuing companies to file a statement disclosing their shareholdings. ${ }^{247}$

Another distinctive aspect of U.S. securities regulation is that it established an efficient, hierarchical system of regulatory bodies. $^{248}$ At the apex of the regulatory system is the SEC, the administrator of the Securities Act of 1933, the Securities Exchange Act of 1934, and five other securities statutes. ${ }^{249}$ The SEC is an administrative agent of the U.S. government and has legislative, executive, and judicial functions. ${ }^{250}$ It has the power to enact rules and regulations for implementing the securities laws, including the Securities Act of 1933 and the Securities Exchange Act of $1934 .^{251}$ It enforces securities laws and regulations, investigates violation of the laws and regulations, and pursues legal actions against violators. ${ }^{252}$ Beneath the SEC are the self-regulation bodies including stock exchanges and the National Association of Securities Dealers, Inc. ${ }^{253}$ The base of the regulatory hierarchy comprises the supervisory bodies of listed companies. ${ }^{254}$ Hence, the United States adopted a regulatory system of central administration based on the self-regulation groundwork.

The U.S. influence can be found everywhere in China's securities system and legislation. China has established a U.S. style

242. Id.

243. MARC I. STEINBERG, UNDERSTANDING SECURITIES LAW 1 (2nd ed. 1996).

244. Securities Act of 1933, 15 U.S.C. $\$ 77$ e (2004).

245. Id.

246. Securities Exchange Act of 1934,15 U.S.C. $\$ 78 \mathrm{~m}(2004)$.

247. Securities Exchange Act of 1934, 15 U.S.C. $\$ 78$ p (2004).

248. See YIE, supra note 45, at 56-57.

249. STEINBERG, supra note 243 , at 2.

250. SEC, supra note 151 .

251. Id.

252. Id.

253. Id.

254. See Maureen O'Hara, Searching for a New Center: US Securities Markets in Transition FED. RES. BANK OF ATL. ECON. REV. 47 (2004). 
regulatory regime over its securities system. ${ }^{255}$ Like the United States, the Chinese securities regulations are provided in a separate code, which models the U.S. securities law in many aspects. $^{256}$ It emphasizes transparency and prevention of market manipulation and forbids the involvement of commercial banks in securities investments. ${ }^{257}$ China also established a concentrated regulatory and administrative system over securities markets and business, which resembles the U.S. regulatory system. The CSRC's functions are similar to those of the SEC. ${ }^{258}$ In addition, the Chinese are calling for further importation of the U.S. experience in areas of disclosure, investor protection, and regulating securities companies. $^{259}$

Nevertheless, it is too early to say that a U.S. style securities system will take root in China, because significant differences exist in the corporate systems of the two countries. In China, the most important and well-performing companies remain wholly owned by the state, and their shares are not tradable on the stock exchanges. ${ }^{260}$ These companies rely substantially on state banks for finance. $^{261}$ Conversely, the largest U.S. companies are all listed public companies. Large Chinese companies usually have the state as the dominant shareholder, while large U.S. companies have dispersed shareholdings. Furthermore, in China, not all shares are freely transferable. ${ }^{262}$ State shares and legal person shares are only

255. When drafting the Securities Law, China's legislators closely studied U.S., Japanese, and Taiwanese legislation, and drew inspiration from their experiences. Japanese and Taiwanese securities laws are all substantially influenced by U.S. legislation. See generally Zhipan Wu, Seeing the Designation of the Administrative System of Securities Business Through the Definition of Securities, in LAW AND PRACTICE, supra note 165, at 4; see also Bing Peng, The US Experience in Regulating Conflicts of Interests of Stock Brokers, in LAW AND PRACTICE, supra note 165, at 119.

256. Id.

257. Since 1995, the United States has relaxed the rules that forbid banks' involvement in securities investments. Japan has followed suit.

258. See Chao Wang, Redesigning China's Regulatory System over Securities Business in Law, in LAW AND PRACTICE, supra note 165, at 35.

259. See generally ZHENZHONG HUANG, CIVIL LITIGATION AND REMEDIES IN US SECURITIES LEgISLATION (2003); See generally SHENG XUEJUN, RESEARCH ON DISClOSURE SYSTEM IN SECURITIES BUSINESS (2004); see also Yang Liang, $A$ Comparison of the Regulatory Systems of the Capital Adequacy of Securities Companies, in LAW AND PRACTICE, supra note 256 at 143-164.

260. See How Large is China's Private Sector? at http://www.flonnet.com/ fl2221/stories/20051021001708700.htm (last updated Oct. 08, 2005).

261. See WEI, supra note 156 , at 142.

262. Han Zhiguo, The Mechanisms of Development and Innovation of China's Corporate Economy, 1 SEC. L. REV 320 (2001). 
allowed to be transferred among state-owned companies or legal persons. ${ }^{263}$ They are not tradable on the securities market. ${ }^{264}$ As a result, only $34.13 \%$ of the total issued shares are freely tradable on the securities market. ${ }^{265}$

China's current situation of corporate development, and its policy of keeping important trades and companies under state control, suggest that the country's aspiration to develop a U.S. style securities market is constricted by its social, political, and economic systems. It may, therefore, be more desirable for China to promote the role of its banks in corporate finance at the present stage, and to gradually carry out the transition from a bank-based system to a U.S. style market-based system.

\section{Can any Inspiration be Drawn From the German Experience?}

In Germany, it is not a popular practice for companies to raise funds by issuing securities on the securities market. ${ }^{266}$ Historically, German banks have been the main source of corporate finance in the country. ${ }^{267}$ Banks charge a low interest rate on bank loans ${ }^{268}$ and usually underwrite the shares of companies. ${ }^{269}$ Consequently, Germany has a less active securities market and fewer listed companies than both the United States and the United Kingdom. ${ }^{270}$

Historically, debentures were subject to double taxation. Shareholders had to pay tax on the dividends they received, after the companies had been taxed on the profits out of which the dividends had been paid. ${ }^{271}$ Loan interest, however, was not doubly taxed. ${ }^{272}$ The interest income from bank accounts are taxed at a

263. Id.

264. Id.

265. See Han Zhiguo, The Mechanisms of Development and Innovation of China's Corporate Economy, 1 SEC. L. REV 320 (2001).

266. Robert Edesess, The End of Innocence: An Actual Knowledge Threshold for Intermediaries Holding Fiduciaries/Clients' Assets, 2 DEPAUL Bus. \& COM. L. J. 377, 418 n. 9 (2004).

267. See WEI, supra note 156, at 142.

268. ECONOMIST INTELLIGENCE UNIT, COUNTRY COMMERCE GERMANY $\S 9.1$ (2004), available at 2004 WLNR 13986210.

269. Cheffins, supra note 157, at 498.

270. See Edward S. Adams, Corporate Governance After Enron and Global Crossing: Comparative Lessons for Cross-National Improvement, 78 IND. L. J. 723, 761 (2003).

271. See Sigurt Vitols, The Transition from Banks to Markets in the GERMAN AND JAPANESE FinANCIAL SYSTEMS 10 (Working Group on Insts., States, and Mkts., Discussion Paper No. P 02-901, 2002).

272. YIE, supra note 45 , at 62-63. 
rate much lower than the dividend income. As a result, many investors chose to deposit their money in a bank, rather than invest in securities. ${ }^{273}$ This was also an important factor which negatively affected the vitality of the securities market in Germany. ${ }^{274}$ The German experience is in contrast with other major modern economic regimes such as the United States and the United Kingdom, but similar to the Japanese financial system. ${ }^{275}$

At a time when nations are fiercely competing for capital investment, Germany has gradually shown interest in the idea of enhancing the function of the securities market in corporate development. ${ }^{276}$ Since the 1970 s, Germany reduced the tax rate on dividends $^{277}$ and took important steps to establish U.S. style regulation of the securities market. ${ }^{278}$

In China, some scholars are reflecting on the benefit of promoting a banks-based financial system or a hybrid system that combines the strengths of banks and markets. ${ }^{279}$ Presently, Chinese banks are prohibited from engaging in speculative activities. ${ }^{280}$ The reasons behind the policy mainly include:

- First, to protect the customers of banks. ${ }^{281}$ If banks were allowed to participate in stock market activities, they would be likely to invest in high risk and high return businesses. With funds locked in such investments, banks might be unable to prerform their primary function of repaying principal and interest on time. In addition, when the companies in which the banks hold shares or other securities experience difficulties, the depositors would likely withdraw their money from the banks, worried that the banks could

273. Id.

274. Caroline Fohlin, Regulation, Taxation, and the Development of the German Universal Banking System, 6 EUR. REV. OF ECON. HIST. 221, 252 (2002).

275. See generally YIE, supra note 45, at 62-64.

276. See VITOLS, supra note 271 , at 18.

277. Francene M. Augustyn, A Primer for Incorporating Under the Income Tax Laws of France, Germany, or the United Kingdom, 7 NW. J. INT'L. L. \& BUS. 267, 281 (1985).

278. See VITOLS, supra note 271, at 12.

279. See, e.g., Amy Wu, PRC's Commercial Banking System: Is Universal Banking a Better Model?, 37 Colum. J. TRANSNAT'L L. 623, 633 (1999).

280. See COMMERCIAL BANKING LAW, art. 43 (1995) (P.R.C.), reprinted in ASIA LAW \& PRACTICE, COMMERCIAL Banking LAW IN THE PRC: ESTABlishing a Foreign COMMERCIAL BANKING OPERATION IN CHINA 68 (1995).

281. See Pan Pan, Legal Restrictions on the Right of Commercial Banks in Making Securities Investments, in LAW AND PRACTICE, supra note 156, at 50. 
be affected negatively. This would, in turn, trigger a series of crises. For the purpose of protecting the depositors of banks, it is necessary to separate banks from the securities market;

- Second, to avoid amplification of risks. ${ }^{282}$ Banks are likely to rescue poorly performing companies in which they themselves hold securities by continuing to purchase the securities of these companies, in order to avoid losses. Or the banks may want to help out the companies by making loans to them. Such decisions would not be made in the best interests. of the depositors. Furthermore, such actions of the banks would increase the risk to investments; and

- Third, to avoid the banks' conflicts of interests. ${ }^{283}$ When banks perceive difficulty of assisting the companies by taking further securities, they may encourage their customers to purchase securities of the companies in which the banks themselves hold securities. Such behavior could shatter public confidence in banks.

On the other hand, many in China see the benefits of banks' involvement in the securities business and in corporate finance generally. Some point out that the advantages of including banks in the securities business definitely outweigh the disadvantages. ${ }^{284}$ Forbidding banks to participate in securities activities is a very expensive method of avoiding the risks that banks' participation could bring to securities business. ${ }^{255}$ An absolute restriction of banks' involvement in securities business would bring economic inefficiency. ${ }^{286}$ Cheaper methods should be used to avoid or mitigate such risks. Bank participation in securities activities can reduce costs of services and encourage competition. When banks strategically invest their money in different trades and companies, their ability to withstand risks is actually strengthened. ${ }^{287}$ Most importantly, bank participation in the securities business would

\footnotetext{
282. Id. at $50-51$.

283. Id. at 50 .

284. Id. at 72 .

285. See, e.g., Wu, supra note 279 , at 630 .

286. Pan Pan, supra note 281, at 72 .

287. Art Alcausin Hall, International Banking Regulation into the 21st Century: Flirting with Revolution, 21 N.Y.L. SCH. J. INT'L \& COMP. L. 41, 74 (2001).
} 
enhance competitive capacity of China's enterprises in the international market.

Since China's entry into the WTO, Chinese enterprises and financial institutions have been further exposed to international competition. ${ }^{288}$ Chinese banks should play a more strategic role in supporting national enterprises and protecting national industries. In the meantime, Chinese banks face challenges from foreign banks. ${ }^{289}$ Further restricting Chinese banks' business activities could do them more harm than good. Therefore, the German experience of establishing a bank-based financial system and gradually introducing market factors does seem a useful reference for the Chinese.

\section{CONCLUSION}

The development of the securities market in China has been driven by two primary purposes: first, to utilize domestic savings to facilitate social funds and private companies; and second, to establish a modern Corporate Governance System in the listed companies.

Significant achievement has been made. Within ten years, China established two national stock exchanges, enacted the Securities Law and a number of relevant regulations, and founded the administrative body, the CSRC. By 2000, over 1,000 Chinese companies were listed on domestic stock exchanges. ${ }^{290}$ The total amount of capital traded on the two national exchanges accounted for $50 \%$ of China's GDP. ${ }^{291}$

Despite these achievements, the development of the Chinese securities business has also unearthed some serious regulatory and practical problems, inherent in the securities business in China. The accumulation of those problems has markedly contributed to the current stock market slump. It is time for the Chinese to think purposefully and plan the future development of the securities market carefully. First of all, China has to answer the question: should China follow the U.S. model by developing a sophisticated securities market as the main resource of corporate finance? It seems that Chinese securities law and practice have been

288. China's Resource Bid, Editorial, THE GlobE \& MAIL, Oct. 22, 2004, at A18.

289. Brian Kelleher, Foreign Banks Target China, AUSTRALIAN BANKING \& FIN., Nov. 17, 2004, at 2.

290. DEHUAN, supra note 3 , at 4 .

291. Id. at 11. 
substantially influenced by U.S. laws and practice. Yet, in the process of building a modern corporate system and a financial system, China has faced different social, political, and economic challenges and has followed its own path of development. China's particular social, political, and economic situations suggest that China may not wholeheartedly embrace a U.S. style of corporate financial system and securities regulatory regime. At the current stage of development, it may be more desirable that China develop a financial system that combines the strengths of the market-based approach and the bank-based approach.

To ensure that the securities market becomes a fair and reasonable trading place for investors, the Chinese government does need to reduce direct governmental intervention to allow the market to operate under market rules. Efforts should also be made to improve the current Securities Law and corporate governance of listed companies. It is interesting to note that China expected its securities market to promote sound practice of corporate governance in listed companies, to help it speed up the establishment of a modern corporate governance system. It appears that this does not necessarily follow in such a unilateral way. The evidence from modern economies is that a wellfunctioning securities market and a sound system of corporate governance are mutually dependent: the development of the securities market provides an external monitoring mechanism of corporate governance, and good practice of corporate governance does, in turn, ensure the orderly operation of the securities market. To build a modern corporate governance system, however, China needs to make further efforts to rationalize the shareholding structure in its companies. It needs to curtail inside control and improve its securities regulation. 